\title{
Evaluation of the PCC slabs of the bus corridors of Anapolis according to its
}

\section{extension}

\author{
Avaliação das placas de CCP dos corredores de ônibus de Anápolis em função da sua extensão \\ Evaluación de las losas de PCC de los corredores de autobuses de Anápolis según su extensión
}

Received: 08/27/2021 | Reviewed: 09/02/2021 | Accept: 09/08/2021 | Published: 09/11/2021

Matheus Silva Oliveira
ORCID: https://orcid.org/0000-0001-9148-5936
Federal Institute of Education Science and Technology of Goiás, Brazil
E-mail: engmatheus.castelli@ @mail.com
Claudia Azevedo Pereira
ORCID: https://orcid.org/0000-0003-0185-8511
Aeronautical Institute of Technology, Brazil
E-mail: claudia.azevedo@ita.br

\begin{abstract}
The Brazilian law $\mathrm{N}^{\circ} 12.587 / 12$ on urban mobility, currently in effect, aims to ensure the improvement of accessibility, and the trafficability of people and cargo in cities, as well as integrate transport modes, and study mechanisms for infrastructure management. Cities with a population of more than 20,000 had to create their urban mobility plans, according to the requirements of the Ministry of the City. The objective of the plan is to conceive projects that aim to mitigate operational and functional problems in the transportation network within the municipalities. One of these cities that is creating a mobility plan is Anápolis-GO, where its plan includes the implementation of bus lanes on the main avenues of the municipality. In these corridors, there was the substitution of the flexible pavement by slabs of PCC (Portland cement concrete), at the boarding and alighting points, due to the sudden braking events and occasional acceleration. Given this scenario, the study aimed to analyze the stopping distance at these locations, as a function of road speed and braking rate, to assess whether the length of these slabs would be sufficient to what was proposed. In addition, it was sought to monitor the pavement against the performance of the PCC slabs, given the incident loads of braking and acceleration, as well as the performance of the flexible pavement, predicting the possible consequences and/or pathologies that may occur due to the operation, since the existing traffic in the corridors should be compatible with that of a high-speed road.
\end{abstract}

Keywords: Bus corridors; Pavement; PCC slabs.

\section{Resumo}

A lei brasileira $\mathrm{N}^{\circ} 12.587 / 12$ sobre mobilidade urbana, atualmente em vigor, visa assegurar a melhoria da acessibilidade, e a trafegabilidade de pessoas e cargas nas cidades, bem como integrar modos de transporte, e estudar mecanismos de gestão de infraestruturas. Cidades com população superior a 20.000 habitantes tiveram que criar seus planos de mobilidade urbana, de acordo com exigências do Ministério da Cidade. Cujo objetivo do plano é conceber projetos que visem atenuar problemas operacionais e funcionais à nível da rede de transportes, dentro dos municípios. Uma destas cidades que está criou o plano de mobilidade foi Anápolis-GO, onde seu plano abrange a implementação de corredores de ônibus nas principais avenidas do município. Nestes corredores, o pavimento flexível foi substituido por lajes de CCP (Concreto de Cimento Portland), nos pontos de embarque e desembarque, devido aos eventos de frenagem brusca e aceleração pontual. Face a este cenário, o estudo em questão teve como objetivo realizar a análise da distância de parada nestes locais, em função da velocidade da pista, e da taxa de frenagem, para avaliar se a extensão destas lajes seriam suficientes ao que se propoz. Além disso, buscou-se realizar o monitoramento do pavimento frente o desempenho das lajes de CCP, dadas as solicitações incidentes de frenagem e aceleração, bem como o desempenho do pavimento flexível, prevendo as possíveis consequências e/ou patologias que possam ocorrer em função da operação, uma vez que o tráfego existente nos corredores deve ser compatível com a de uma via de alta velocidade.

Palavras-chave: Corredores de ônibus; Pavimento; Placas de CCP.

\section{Resumen}

La ley brasileña $\mathrm{N}^{\circ} 12.587 / 12$ sobre la movilidad urbana, actualmente en vigor, tiene por objeto garantizar la mejora de la accesibilidad y la transitabilidad de las personas y las cargas en las ciudades, así como integrar los modos de transporte, y estudiar los mecanismos de gestión de las infraestructuras. Las ciudades de más de 20.000 habitantes tenían que crear sus planes de movilidad urbana, de acuerdo con los requisitos del Ministerio de la Ciudad. El objetivo 
del plan es diseñar proyectos para mitigar los problemas operativos y funcionales de la red de transporte en los municipios. Una de estas ciudades que está creando un plan de movilidad fue Anápolis-GO, donde su plan incluye la implantación de carriles bus en las principales avenidas del municipio. En estos corredores, se produjo la sustitución del pavimento flexible por losas de CCP (hormigón de cemento Portland), en los puntos de embarque y desembarque, debido a los sucesos de frenado brusco y aceleración ocasional. Ante este escenario, el estudio pretendía analizar la distancia de frenado en estos lugares, en función de la velocidad de la carretera y de la tasa de frenado, para evaluar si la longitud de estas losas sería suficiente para lo propuesto. Además, se buscó monitorear el comportamiento del pavimento frente a las losas CCP, dadas las cargas incidentes de frenado y aceleración, así como el comportamiento del pavimento flexible, prediciendo las posibles consecuencias y/o patologías que puedan ocurrir debido a la operación, ya que el tráfico existente en los corredores debe ser compatible con el de una vía de alta velocidad.

Palabras clave: Corredores de autobuses; Pavimento; Losas de PCC.

\section{Introduction}

Recently with the accelerated growth of cities, linked to the constant increase in population and the country's car fleet, it was observed that several cities did not have adequate urban planning, so the Ministry of Cities in Brazil realized the need for a policy dealing with urban mobility within municipalities. On January 3, 2012, Law No. 12,587, which regulates the National Policy on Urban Mobility, came into force, and it became mandatory to draw up a Mobility Plan in cities with over 20,000 inhabitants, which was previously required only for cities with a population density of over 500,000 inhabitants (Brasil, 2012).

According to Article 7 of the referred Law, the National Urban Mobility Policy has as its main objective to promote improvements in the urban conditions of the population in terms of accessibility and mobility, to increase the movements of people and cargo in cities (Cidades, 2007).

Since according to Vieira et al., (2021), mobility depends on the level of adequacy between personal characteristics or the object you want to transport, with the capacity and conditions of the transportation system and the condition of the infrastructure, including here all possible types of trips.

Through this new determination of the Ministry of Cities, the Anapolis City began its urban mobility plan whose objective would be a greater fluidity of traffic of vehicles and people in the city with the modification of several aspects in the urban scenario, among them the construction of infrastructure works and bus corridors.

Making a brief analysis of the Anápolis city, there is the perception that one of the main reasons for these changes necessities and, transformations are happening in its urban perimeter, this is due to the deficiency regarding urban planning.

According to IBGE (2018), the city population of Anapolis is currently approximately 375,142 inhabitants. The city has the 3rd largest GDP (Gross Domestic Product) of the state and is in constant socio-economic growth, with the implementation of several infrastructure works such as the cargo airport for large aircraft and the North-South railroad.

Thus, the region of Anápolis starts to serve as strategic support in the logistic assistance of the Brasília-Goiânia axis, where due to this change of scenery, the city presented an accelerated growth leading to a serious problem, the absence of mobility.

To fulfill the mobility policy, the urban mobility plan of Anapolis was prepared in 2015, whose modifications and changes of greater impact would be in the creation of six bus corridors in high-speed traffic, with minimal characteristic elements of a BRT (bus rapid transit) following the guidelines of the Institute of Transport and Development Policies to Brazil (ITDP,2016). And the construction of two viaducts, on the main avenue of the city, connecting the city from north to south.

On the bus corridors, PCC slabs were set up at the bus stop. However, when the construction work began, there ere questions about whether these modifications would have functionality and serve the purpose that was planned.

Concrete, in itself, has interesting properties for application in pavement works. Among these properties it is possible to mention its fluidity, allowing easy handling of the material. Besides the excellent mechanical behavior, with high resistance 
to compression efforts (Bauer, 2015). Thus, these slabs are used due to the problems that can be caused by the plastic deformation in pavements due to the demands that these vehicles can generate, mainly regarding their acceleration and deceleration.

However, it is questionable whether the length of these slabs would be sufficient for the acceleration and deceleration operation, especially because the local speed and the braking-acceleration rate are often not smooth at the bus stop. Thus, an analysis of these CCP slabs is made at bus stops, to know the dimensioning guidelines and the choice of modifying the infrastructure in these specific points, taken as a premise the speed allowed in the street where the corridor is inserted.

The objective of this research is to study the length of the PCC slabs at the boarding and disembarking points of six bus corridors and then to analyze the braking distance traveled by the buses as a function of the speed incident on the track, to assess whether the lengths of these slabs will actually be enough for what is intended. Therefore, it is aimed to calculate the stopping distance on these structures, adopting the most critical situation, in other words, when the pavement is wet and has the lowest friction and adherence tire pavement, where it will automatically cause a longer braking distance, and thus monitor the pavement and predict the possible pathologies that can affect these structures and in the flexible pavement due to the movement of the slabs and the junction between rigid and flexible pavement.

\section{Methodology}

The methodology adopted in this work will be based on teh assumptions of the geometric design of roadways, presente by Pontes Filho (1998), using the verification of the visibility stop distances. Thus, a study of the literature regarding these calculations is being made and they will be applied to the situation of the Anapolis bus corridors.

In this way, depending on the speed limit in the six bus corridors, it is intended to determine whether, once the braking procedure has been initiated, the extensions of the slabs will be enough for the vehicle to be able to stop without exerting any punctual effort on the flexible pavement, to potentially use the PCC slabs. The possible distress that may appear on the road surface will also be analyzed, depending on the insufficient extension of these slabs over their lifetime.

\subsection{Subject of study}

The Mobility Plan of the city of Anápolis contemplates the implementation of six bus corridors, with coverage in the routes of greater flow and access to the main points of the city of Anápolis, being the avenues Brazil North, Brazil South DAIA, University, San Francisco - JK, Fernando Costa - President Kennedy and Pedro Ludovico, as Figure 1. 
Figure 1- Map with delimitation of the bus corridors of Anápolis-GO.

\section{CORRIDORS:}

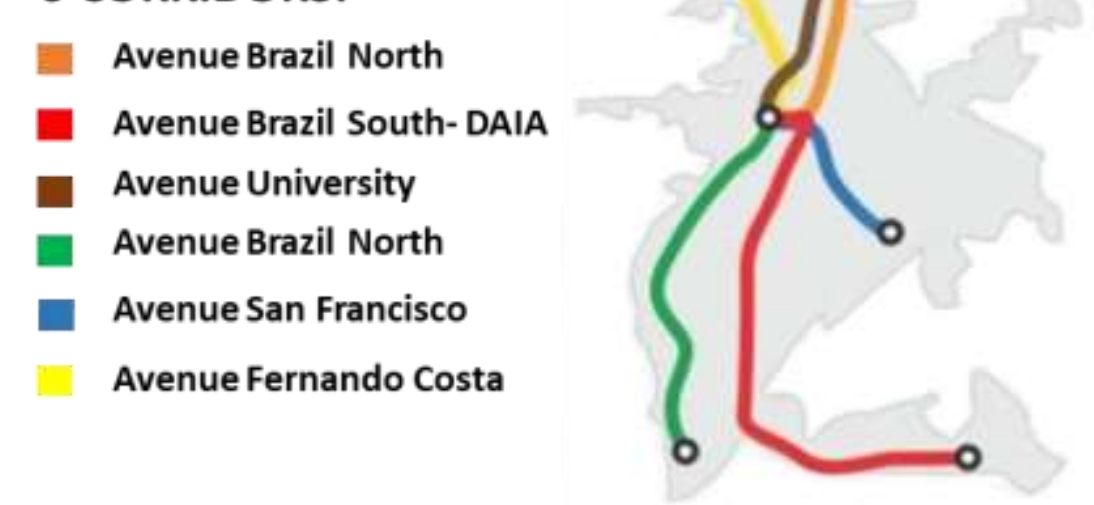

Source: ACIA 2015 (Author adaptations 2021).

Therefore, the six corridors will be considered as case studies, since they operate in two lanes whose speeds in the different routes differ according to their classification:

- Brazil South- DAIA Avenue with a speed limit of $60 \mathrm{~km} / \mathrm{h}$;

- Brazil North Avenue with a speed limit of $60 \mathrm{~km} / \mathrm{h}$;

- Pedro Ludovico Avenue with a speed limit of $60 \mathrm{~km} / \mathrm{h}$;

- San Francisco Avenue-JK with a speed limit of $40 \mathrm{~km} / \mathrm{h}$;

- Fernando Costa Avenue- President Kennedy with a speed limit of 40km/h;

- And, University Avenue with a speed limit of $40 \mathrm{~km} / \mathrm{h}$.

These corridors are in constant operation receiving a large number of public transportation lines during the day (Global, 2017).

\section{Discussion}

The level of operability, as well as the economy of a transport system, is directly related to the conditions of the infrastructure, more exactly to the quality of the rolling surface of the pavement (Kropác \& Múčka, 2009). Since pavements with low or poor serviceability indexes, besides causing losses to the operation, lead to higher fuel costs, higher rolling stock operating costs, and compromise the safety of the operation.

When the functionality of a pavement structure is analyzed, the operations performed on this structure are evaluated, analyzing if the safety and transportation economy indicators are not being impaired. Thus, it is possible to relate directly, the pavement condition index, with the operational costs, fixed and variable transportation, as well as the comfort and safety of the operation. The fact that the functional condition of the pavement directly affects the calculation of this index, resulting in performance indicators and usefulness (Oliveira et al., 2020).

\subsection{Dimensions of PCC slabs}

For the execution of the PCC slabs, the flexible pavement is removed, i.e. the surfacing, base, and subbase layers of the existing pavement there. Afterward, the slabs are built in the rigid bus stops, to work well with the imposed traffic, since the elasticity modulus of this type of pavement is higher, that is, the more rigid the material, the lower the deformation for a certain tension, thus resisting better to the formation of wheel tracks in the bus corridors pavements. 
For the construction of the CCP slabs, in situ density analysis was performed using the sand bottle standardized by NBR 7185-2016, to calculate the apparent dry specific mass and consequently the degree of soil compaction of the subgrade, in all bus stops of the corridors, as well as analysis of obtaining CBR from these sections (ABNT, 2016).

After all the analyses and possession of the data, the methodology of calculation and design of the PCC slabs was defined, based on the PCA-1984 (Portland Cement Association) and AASHTO-1981 method, which considers that the selection of thicknesses for rigid Portland cement concrete pavements is based on limiting the deformation, or tensile stress in the slab to some tolerable level, this tolerance is directly related to the stiffness of the material (Southgate \& Deen, 1984).

Whose profile was considered more appropriate to the scenario of these corridors, was composed of the compaction of the subgrade, then reinforcement of the subgrade with granular material type, then a base layer using Cemented Crushed Stone - CCS with geotextile reinforcement, and then the confection of reinforced concrete slabs with compressive strength, equivalent to a Fck of $32 \mathrm{MPa}$, as shown in Figure 2, with the structure with a total thickness of $47 \mathrm{~cm}$ deep.

Figure 2 - Preparation of the PCC slabs.

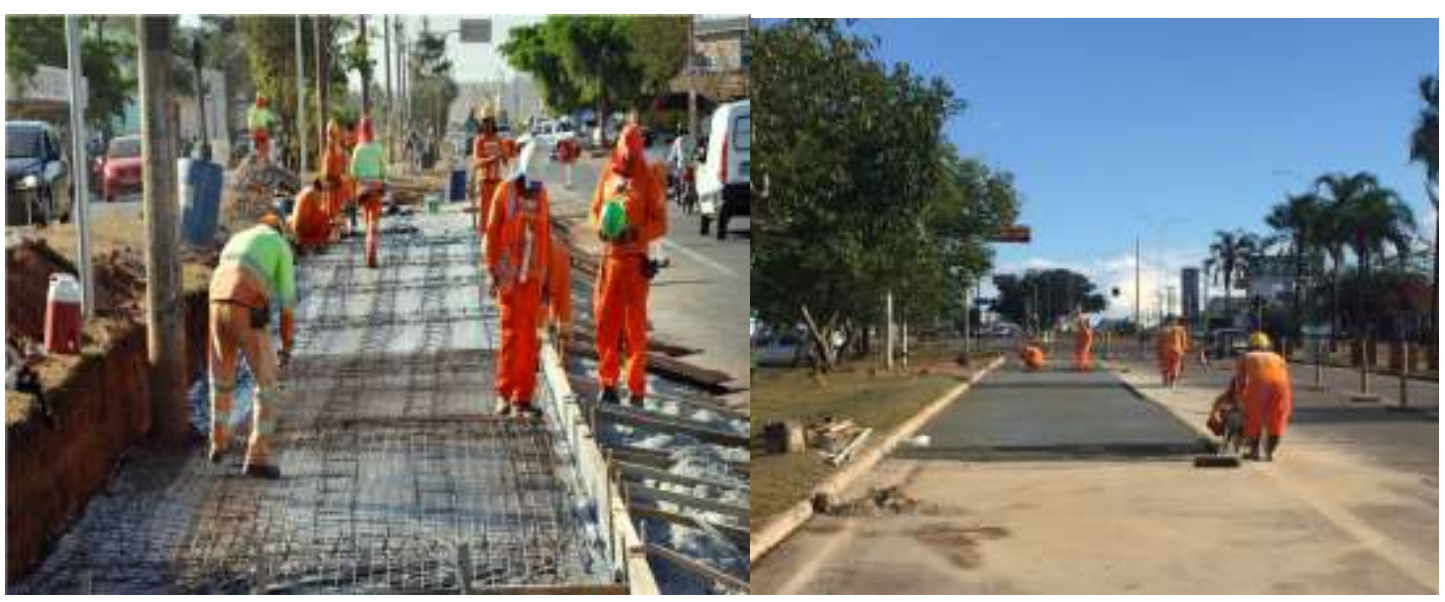

Source: Authors (2018).

The geometry of the sized slabs presents a configuration whose purpose is to receive the demands imposed by the action of traffic daily and to be able to support the efforts that are generated in the pavement, due to acceleration and deceleration so that the structure can resist these efforts with the least possible deformation.

Even though some corridors have a higher average daily volume of vehicles, it was decided to standardize the geometry of these slabs, whose configuration consists of $35 \mathrm{~m}$ of total extension and $3.20 \mathrm{~m}$ of width for corridors with a permitted speed of $40 \mathrm{~km} / \mathrm{h}$, and for those operating at $60 \mathrm{~km} / \mathrm{h}$ they have a total extension of $55 \mathrm{~m}$, and $3.20 \mathrm{~m}$ of width, with each expansion joint at 5 linear meters, as shown in Figure 3. 
Figure 3 - Geometry and extension of the PCC slabs.
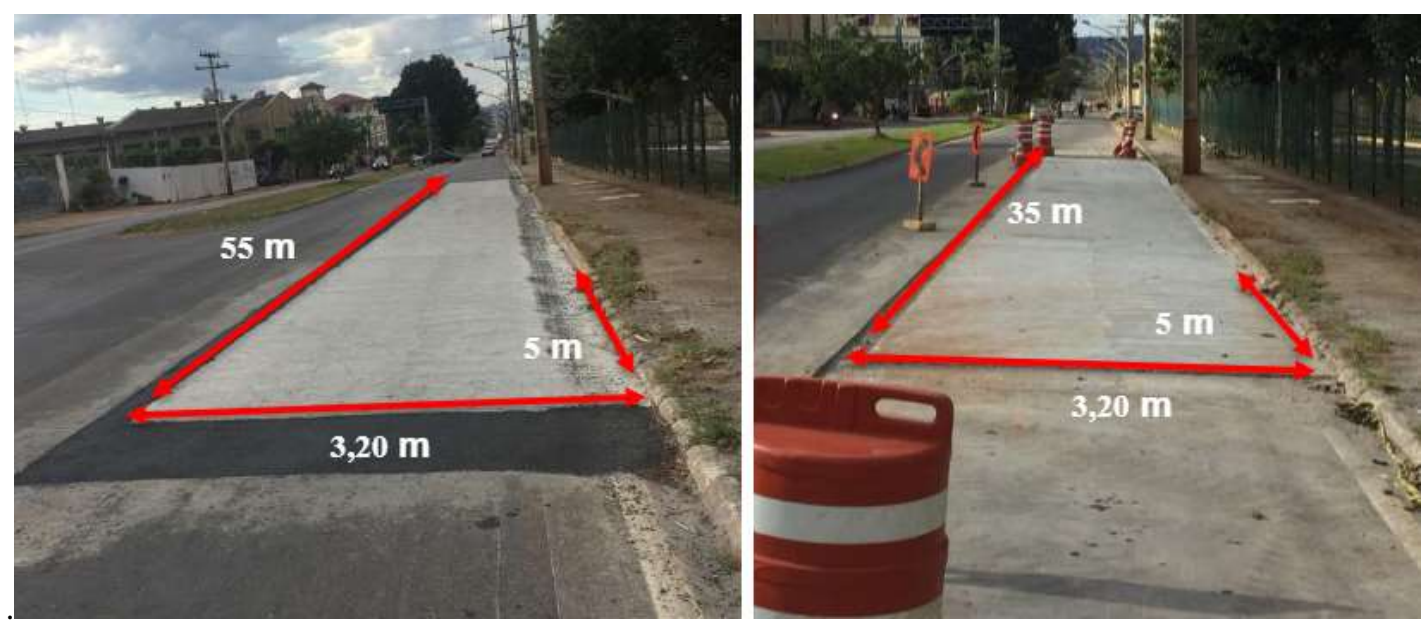

Source: Authors (2018).

\subsection{Stopping visibility distance}

According to Pontes Filho (1998), the stopping visibility distance is defined as the distance a vehicle travels, from the driver's perception of an obstacle to the vehicle's complete stop. The time of perception and reaction is the distance traveled by the driver from the moment he sees the obstacle until the moment he starts braking. The other portion is attributed to the distance traveled by the vehicle during braking, as shown in Figure 4. DNIT's Geometric Design Manual for Rural Roads (DNER 706 Publication, 1999) treats the stopping visibility distance as an extension of the road ahead, where the driver, after seeing an obstacle in front of him, can stop without the vehicle being hit.

Figure 4 - Schematization of stopping distance.

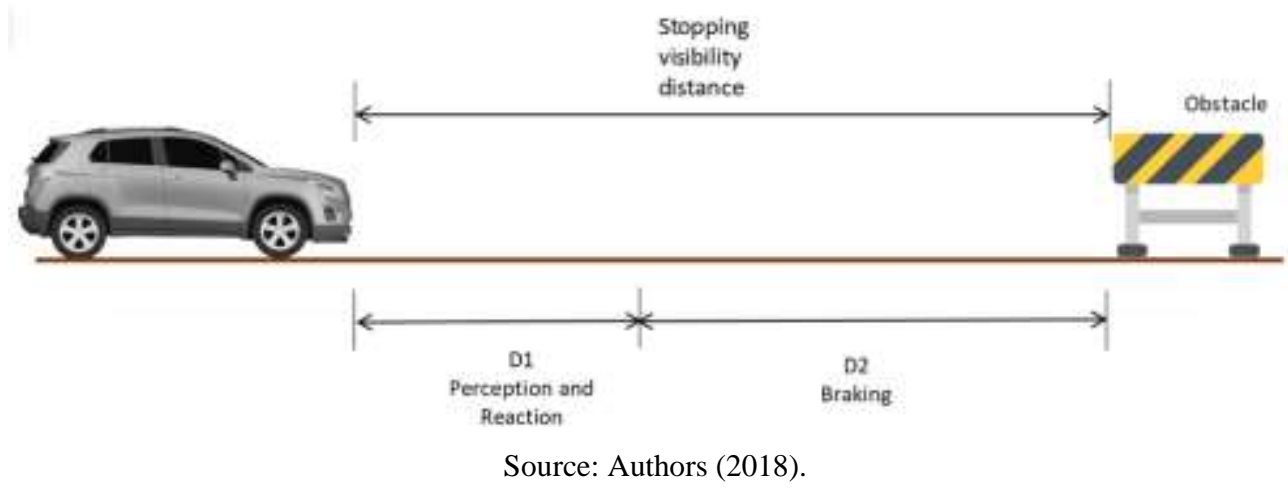

As mentioned by Pontes Filho (1998), the AASTHO recommends that a perception and reaction time equivalent to 1.5 seconds should be assigned for the perception of an obstacle and 1.0 seconds for the reaction and braking procedure. This results in a total perception and reaction time of 2.5 seconds. This portion is calculated by the following equation 1 :

$$
\begin{aligned}
& \mathrm{D}_{1}=\mathrm{v} \cdot \mathrm{t} \\
& \mathrm{D}_{1}=\mathrm{v} \cdot 2,5
\end{aligned}
$$

Where:

$\mathrm{D}_{1}=$ distance travelled between reaction time and perception, in meters, $\mathrm{v}=$ speed in $\mathrm{m} / \mathrm{s}$, and 
$\mathrm{t}=$ time in seconds.

However, the unit used to ascertain the operating speed of vehicles on urban roads is $\mathrm{km} / \mathrm{h}$, and conversion is required according to the equation 2 :

$$
D_{1}=v \cdot 0,7
$$

Where:

$\mathrm{D}_{1}=$ distance travelled between reaction time and perception, in meters, and, $\mathrm{v}=$ speed in $\mathrm{Km} / \mathrm{h}$.

For the calculation of the portion traveled by the vehicle during braking, principles of physics are used, a priori of the kinetic energy of the vehicle $(\mathrm{Ec})$, where this energy is annulled by the friction force along with the braking distance $(\tau \mathrm{Fa})$, resulting in an equation 3 :

$$
\begin{gathered}
\Delta \mathrm{Ec}=\tau \mathrm{Fa} \\
\frac{m \cdot v^{2}}{2}=P . f . \mathrm{D}_{2}=m . g . f \cdot \mathrm{D}_{2} \\
\mathrm{D}_{2}=\frac{v^{2}}{2 \cdot g \cdot f}=\mathrm{D}_{2}=\frac{\left(\frac{V}{3,6}\right)^{2}}{2 \cdot 9,8 \cdot f} \\
\mathrm{D}_{2}=\frac{V^{2}}{255(f+i)}
\end{gathered}
$$

Where:

$f=$ longitudinal tyre/pavement friction coefficient;

$i=$ greide in $\mathrm{m} / \mathrm{m}$ (ascending + , descending - );

$m=$ mass (qual unidade está?), and

$g=$ acceleration due to gravity (unidade).

Thus, the stopping distance of visibility is determined by equation 4 :

$$
D p=0,7 \cdot V+\frac{V^{2}}{255(f+i)}
$$

Where:

$\mathrm{D}_{\mathrm{p}}=$ Stopping distance

Attention should be paid to the coefficient of longitudinal friction since it expresses the efficiency of the braking process, which is seasonal depending on the dry and wet conditions of the pavement, as shown in Figure 5 and Table 1: 
Figure 5 - Graphic of the speed by longitudinal coefficient of friction in wet and dry pavements.

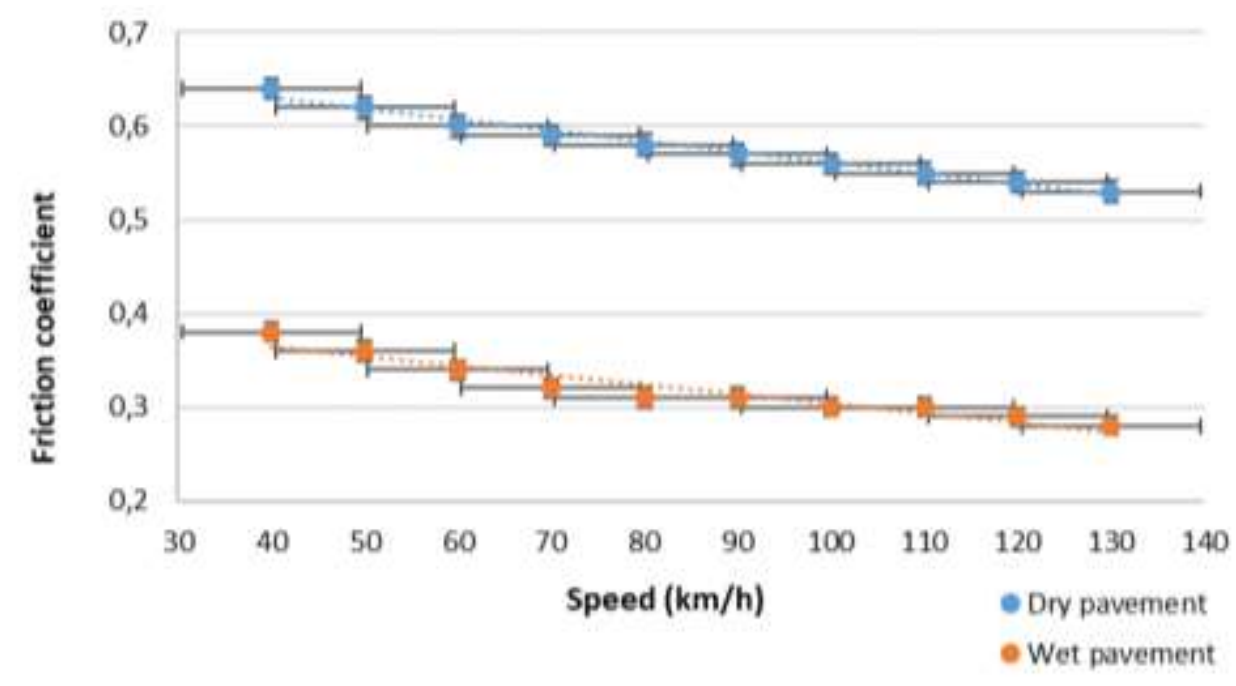

Source: Authors (2018).

Table 1 - Table of longitudinal friction coefficient. DNER (Author adaptations 2021).

\begin{tabular}{ccc}
\hline & \multicolumn{2}{c}{ Coefficient of longitudinal friction } \\
\hline Speed $(\mathbf{k m} / \mathbf{h})$ & Dry Pavement & Wet Pavement \\
\hline 40 & 0,64 & 0,38 \\
50 & 0,62 & 0,36 \\
60 & 0,60 & 0,34 \\
70 & 0,59 & 0,32 \\
80 & 0,58 & 0,31 \\
90 & 0,57 & 0,31 \\
100 & 0,56 & 0,30 \\
110 & 0,55 & 0,30 \\
120 & 0,54 & 0,29 \\
130 & 0,53 & 0,28 \\
\hline
\end{tabular}

Source: DNER (1999) (Author adaptations 2021).

It can be seen from Figure 5 and Table 1 that the pavement in the wet condition has a lower braking efficiency compared to the dry condition. Where the pavement with a dry surface achieves braking rates up to $98 \%$ higher than those of wet surfaces. It should be noted that the condition and type of the rolling stock braking devices, the speed reached by the rolling stock and the type of mixture of the pavement surface interfere in the coefficients of friction (DNER, 1999 \& Oliveira et al., 2020).

\section{Results}

\subsection{Calculation of distances in corridors}

The calculation estimate aimed to analyze the two friction conditions, both when the pavement is dry, and also when it is in its worst condition, i.e., with the wet pavement surface, being calculated the distance for the 6 corridors since they operate with different Average Daily Volume and allowed speed. Once the calculations were carried out, the following distances were reached, presented in Figure 6 and Table 2. 
Figure 6 - Graphic of the stopping distance in bus corridors in wet and dry pavements.

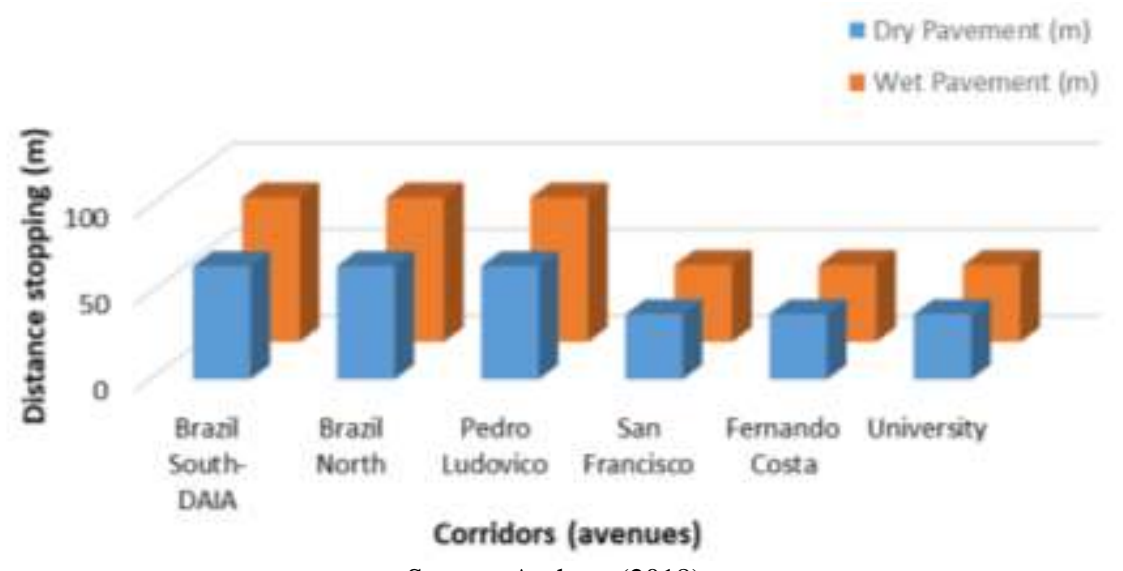

Source: Authors (2018).

Table 2 - Table of stopping distance in bus corridors.

\begin{tabular}{lccc}
\hline \multicolumn{1}{c}{ Corridors } & Allowed speed & $\begin{array}{c}\text { Distance stopping } \\
\text { Dry Pavement } \\
(\mathbf{m})\end{array}$ & $\begin{array}{c}\text { Wet Pavement } \\
(\mathbf{m})\end{array}$ \\
\hline Brazil South- DAIA & 60 & 65,53 & 83,52 \\
Brazil North & 60 & 65,53 & 83,52 \\
Pedro Ludovico & 60 & 65,53 & 83,52 \\
San Francisco & 40 & 37,65 & 44,51 \\
Fernando Costa & 40 & 37,65 & 44,51 \\
University & 40 & 37,65 & 44,51 \\
\hline
\end{tabular}

Source: Oliveira et al. (2018).

According to the calculations presented in Figure 6 and Table 2, the stopping distances for corridors operating at 60 $\mathrm{km} / \mathrm{h}$ are equivalent to approximately 66 meters and for those operating at $40 \mathrm{~km} / \mathrm{h}$, the stopping distances are 38 meters when the pavement is dry.

However, when a project is carried out, it is generally considered the most unfavorable situation, so the distances required for braking in corridors with operating speeds of $60 \mathrm{~km} / \mathrm{h}$ should be 84 meters and those of $40 \mathrm{~km} / \mathrm{h} 45 \mathrm{~meters}$ long, taking as a premise the wet pavement, which requires a greater extension due to skidding events.

It is important to note that the calculations presented were made without the inclusion of the percentage of inclination of the road, since it is not known, which causes a limitation in the calculation, being adopted as calculation the $0 \%$ inclination according to the DNIT Manual of Geometric Design of Rural Roads (DNER, 1999).

\subsection{Incident distress}

The use of the CCP slabs to replace the flexible pavement in bus corridors was thought to avoid the appearance of problems in the flexible pavement, such as corrugations, depression, rutting, spalling, bumps, and sags of the asphalt layer, and others.

Monitoring the slabs that are already in use, it can be seen that at the junctions between the PCC and flexible pavement, the joints already show damage such as spalling in concrete pavement, accompanied by slippage of flexible material from the pavement. This causes the formation of water slides at the ends of these slabs. 
It can also be noted that other distress in flexible pavements, as well as corrugations and bumps of the asphalt layer, are beginning to appear from the movement of the PCC slabs that move due to the braking and acceleration events of the buses, in addition to large cracking due to material fatigue as a result of repeated traffic loads, which may advance in the future and generate the edge crackings that tangent the PCC slab.

Therefore, it can be observed that due to the movement of the PCC slabs and the deterioration of the flexible pavement, the rigid structure is also subject to distress as well as the appearance of crackings of the PCC slabs, and a problem that is due to the thermal movement or induced by the humidity of the concrete slab.

\section{Conclusion}

For a mobility plan to be complete, it is important to optimize traffic flow. In this context, the city of Anapolis has adopted the use of concrete slabs in the bus stops to avoid defects in the pavement and consequently traffic improvement.

The use of these slabs of PCC in substitution of the flexible pavement in the buses corridors was thought to avoid the appearance of problems in the flexible pavement, such as corrugations, the formation of wheel paths, shoving of the asphalt layer, and others.

Due to the occasional braking and acceleration events, and because it is a rigid material, whose module is high, it was seen that the PCC slabs would be the most appropriate, therefore, in terms of the dimensions and total extension of the slabs groups, there was carelessness on the part of the designers, which to a certain extent puts the functionality of the structure into compromise.

It is possible to conclude that the extension of the PCC slabs to the corridors of the avenues Brazil South, Brazil North and Pedro Ludovico in a certain way are insufficient for the purpose intended, since they have an extension of 55 meters and a width of the CCP slabs of 3.20 meters, where according to the calculations of stop distance, it would be necessary the equivalent of approximately 84 meters of extension, considering a speed of the bus in $60 \mathrm{~km} / \mathrm{h}$, and coefficient of friction for wet pavement, being this structure with efficiency in $65 \%$ of its capacity.

On Fernando Costa, University and San Francisco avenues, one can see that taking into account the calculation of the coefficient of friction between tire pavement for dry pavement, the percentage found is close to the desired situation, according to the calculations for dry pavement would require a distance of 38 meters, in the field an extension of 35 meters by 3.20 wide was adopted, which can be considered satisfactory.

However, it should be noted that the slabs must be capable of enabling braking and acceleration events, so that the braking distance (D2) does not exceed the entire length of the slabs, but that it completes its operation in the percentage of up to $80 \%$ of its useful length. It should be noted that if considered a coefficient of friction for wet pavement, the efficiency of this slab is around $77 \%$, which would require an increase of 10 linear meters.

Therefore, it can be said that in corridors with an operating speed of $60 \mathrm{~km} / \mathrm{h}$, the length of the PCC slabs will be insufficient, since it will exceed a braking distance of 29 meters over the flexible pavement.

Thus, there is concern about the possibility of distress that compromises the pavement life in these corridors as a result of the slabs being shorter than required according to the calculations, the load transfer indexes from the PCC slabs to the flexible pavement becomes more incident, which can generate corrugations in the flexible pavement due to excessive movement of the slab, as well as shoving of the asphalt layer in the joints, and formation of whashboarding between the PCC slabs and the flexible pavement.

However, the monitoring of these structures becomes something strategic to correct possible distress at an early stage, to make preventive and routine maintenance, thus having an extension in the useful life of the pavement. It is worth noting that the increase in the useful life and quality of the pavement has a significant impact on urban mobility since the interdiction to 
carry out repairs as well as the reduction in the speed of traffic due to defects in this pavement generates a decrease in the flow and accumulation of vehicles compromising the quality of the urban traffic system.

It is also worth mentioning that the stopping visibility distances are used to check the suitability of horizontal and vertical curves, within the geometric study of roads, which generates in the work a limitation as to precise results in analyzing whether the CCP slabs will be effective to what is proposed, so it is sought for subsequent work to make a deceleration analysis provided in the car-following models intended for BRT operation, being the closest to the real situation.

As a suggestion for future studies, it is intended to evaluate the tire pavement adherence indexes of PCC slabs using a static test methodology, with an evaluation of the macrotexture through the sand stain test and microtexture through the British pendulum test, to obtain concise data of adherence and friction of the surface of PCC slabs. In addition, it also seeks to perform analyses employing the Car-following model applied to arterial roads and high-speed traffic.

\section{References}

AASHTO (1981). Interim Guide for Design of Pavement Structures, American Association of State Highway and Transportation Officials.

Anápolis (2017). Prefeitura anuncia cronograma de execução de obras dos corredores de ônibus do transporte coletivo: Pense Mobilidade. http://www.pensemobilidade.com.br/2017/08/anapolis-prefeitura-anuncia-cronograma.html.

Associação Brasileira de Normas Técnicas (2016). ABNT NBR 7185:2016. Solo - Determinação da massa específica aparente, in situ, com emprego do frasco de areia. ABNT.

ACIA (2015). Anápolis na Era dos Corredores de Ônibus: Modernidade e Sustentabilidade. http://anapolisglobal.com.br/solucao-inteligente-justa-economicae-ecologica.

Bauer, L. A. Falcão. (2015). Materiais de Construção. (5a ed.), LTC.

Brasil (2012). Definição, Diretriz, Objetivo, Política Nacional, Integração, Meios De Transporte, Transporte Coletivo Urbano, Desenvolvimento Sustentável, Pessoas, Carga. LEI No 12.587, DE 3 DE JANEIRO DE 2012. Política Nacional de Mobilidade Urbana. http://www2.camara.leg.br/legin/fed/lei/2012/lei12587-3-janeiro-2012-612248-normaatualizada-pl.pdf.

Cidades, Ministério das (2007). PlanMob: construindo a cidade sustentável - caderno de referências para elaboração de planos de mobilidade urbana. https://www.mdr.gov.br/images/stories/ArquivosSEMOB/Biblioteca/LivroPlanoMobilidade.pdf.

DNER - Departamento Nacional de Estradas de Rodagem (1999). Manual de Projeto Geométrico de Rodovias Rurais. DNER/ABNT.

Global, Anápolis (2017). Anápolis na era dos corredores de ônibus. http://anapolisglobal.com.br/solucao-inteligente-justa-economica-e-ecologica/.

IBGE - Instituto Brasileiro de Geografia e Estatística (2018). População de Anápolis-Goiás: Censo Demográfico de 2018. https://www.ibge.gov.br/cidades-eestados/go/anapolis.html.

ITDP-Instituto de Políticas de Transporte e Desenvolvimento (2016). Elementos Básicos do BRT. http://itdpbrasil.org.br/wp-content/uploads/2015/03/ITDPBrasil_Informativo-Elementos-B\%C3\%A1sicos-do-BRT_em-PT_vers\%C3\%A3o-WEB.pdf.

Kropáč, O., Múčka, P. (2009). Estimativa da ondulação do perfil longitudinal da estrada a partir da régua medição, Journal of Transportation Engineering ASCE, 135 (11), 801-812.

Oliveira, M. S., Pereira, C. A. e Farias, P. C. A. (2020). Applicability of PAVEAIR for Airport Pavement Management: Comparison between Military and Civilian Runways. Journal of Civil Engineering and Architecture, 14 (7), 360-367, doi: 10.17265/1934-7359/2020.07.002

Oliveira, M. S., Pereira, C. A. e Paiva, C. R (2018). Avaliação das Placas de CCP dos Corredores de Ônibus de Anápolis em Função da sua Extensão. 32 Congresso ANPET.

Pontes Filho, G. (1998) Estradas de rodagem projeto geométrico: Distância de visibilidade de parada. Copyright. 432 p.

Vieira, M. G. M., Moreira T. G., Pereira C. A., \& Oliveira A. F., (2021). Reinterpreting of mobility in high traffic streets in the Anapolis-GO downtown. Case Studies on Transport Policy, 9 (2), 767-774. doi: 10.1016/j.cstp.2021.03.013

Southgate H. F., Deen R. C. (1984). Thickness Design Procedure for Portland Cement Concrete Pavements- Transportation Research Program University of Kentucky, $42 \mathrm{p}$. 